\title{
Intimate partner violence against women in western Ethiopia: prevalence, patterns, and associated factors
}

\author{
Sileshi G Abeya ${ }^{1 *}$, Mesganaw F Afework ${ }^{1}$ and Alemayehu W Yalew²
}

\begin{abstract}
Background: Intimate partner violence against women is the psychological, physical, and sexual abuse directed to spouses. Globally it is the most pervasive yet underestimated human rights violation. This study was aimed at investigating the prevalence, patterns and associated factors of intimate partner violence against women in Western Ethiopia.

Methods: A cross-sectional, population based household survey was conducted from January to April, 2011 using standard WHO multi-country study questionnaire. A sample of 1540 ever married/cohabited women aged 15-49 years was randomly selected from urban and rural settings of East Wollega Zone, Western Ethiopia. Data were principally analyzed using logistic regression.
\end{abstract}

Results: Lifetime and past 12 months prevalence of intimate partner violence against women showed 76.5\% (95\% Cl: $74.4-78.6 \%)$ and $72.5 \%$ (95\% Cl: 70.3-74.7\%), respectively. The overlap of psychological, physical, and sexual violence was $56.9 \%$. The patterns of the three forms of violence are similar across the time periods. Rural residents (AOR 0.58, 95\% Cl 0.34-0.98), literates (AOR 0.65, 95\% Cl 0.48-0.88), female headed households (AOR 0.46, 95\% Cl 0.27-0.76) were at decreased likelihood to have lifetime intimate partner violence. Yet, older women were nearly four times (AOR 3.36, 95\% Cl 1.27-8.89) more likely to report the incident. On the other hand, abduction (AOR 3.71, 95\% Cl 1.01-13.63), polygamy (AOR 3.79, 95\% Cl 1.64-0.73), spousal alcoholic consumption (AOR 1.98, 95\% Cl 1.213.22), spousal hostility (AOR 3.96, 95\% Cl 2.52-6.20), and previous witnesses of parental violence (AOR $2.00,95 \% \mathrm{Cl}$ 1.54-2.56) were factors associated with an increased likelihood of lifetime intimate partner violence against women.

Conclusion: In their lifetime, three out of four women experienced at least one incident of intimate partner violence. This needs an urgent attention at all levels of societal hierarchy including policymakers, stakeholders and professionals to alleviate the situation.

Keywords: Intimate partner violence, Women, Prevalence, Patterns, Factors

\section{Background}

Violence against women (VAW) is "....any act of genderbased violence that results in, or is likely to result in, physical, sexual or psychological harm or suffering to women, including threats of such acts, coercion or arbitrary deprivation of liberty, whether occurring in public or in private life" [1]. Since women are disproportionately affected than men (95\% Vs 5\%), gender based

\footnotetext{
* Correspondence: garomaabe@yahoo.com

'Departments of Reproductive Health, Population and Nutrition, School of Public Health, Addis Ababa University, P.O. Box 9086 Addis Ababa, Ethiopia Full list of author information is available at the end of the article
}

violence is often used interchangeably with violence against women $[2,3]$. Furthermore, the most common and universally occurring (85\%) form of VAW is that perpetrated by a husband or other intimate partners [3-5].

Intimate partner violence against women (IPVAW) is the most pervasive yet under estimated social and health problem that occur in pandemic proportions [2-8]. The proportion is comparable to those for cancer, cardiovascular disease, HIV/AIDS, malaria, and traffic accident in the world $[2,5,9,10]$. In fact, it becomes increasingly known as a health and human rights concern, and

\section{Biomed Central}


prevents women's enjoyment of their fundamental right and freedom that can hinder development $[3,4,11]$.

In spite of the definitions and methodological differences, several population-based studies from around the world indicated that $10 \%-71 \%$ of married or cohabited women have experienced IPVAW $[2,5,12,13]$. On the other hand, World Health Organization (WHO) multicountry study on VAW in 10 different countries confirmed that the lifetime and current (past 12 months) prevalence of physical or sexual violence ranges between 15 and $71 \%$ and $4-54 \%$, respectively. According to the findings of the study, the lowest rates have been found in Japan and the highest in Ethiopia, Peru, and Bangladesh [14].

The root causes of intimate partner violence against women are diverse and there is no single factor that explains further why some individuals are violent, or why violence is more prevalent in some communities than in others [2,4-6]. Rather, several complex and inter connected social and cultural factors are involved. Indeed, all of them are manifestations of unequal power relations between men and women [15]. Moreover, an ecological model for understanding the factors of IPVAW was described at the levels of individual, relationships, community, and society $[5,15]$.

In Ethiopian context, although women represent $49.8 \%$ of the population and highly contribute to socioeconomic development, they occupy lower status than men. They experience longer working days, low levels of education, and lack of adequate assignments in leadership and decision making positions [16]. However, studies from Ethiopia on IPVAW are few irrespective of different lifestyles, customs and culture of the people [16]. According to a handful of available population based studies from the northern and southern part of the country, the prevalence of IPVAW varies from 50 to $71 \%$ during lifetime and $30-54 \%$ for past 12 months [17-21].

Yet, in western part of the country where the culture of the community is fairly different, population based study on IPVAW is hardly found. Thus, this research was aimed at investigating the extent, patterns, and associated factors of IPVAW in a sample of women aged 15-49 years living in urban and rural settings of East Wollega Zone, Western Ethiopia.

\section{Methods}

The study was conducted in one urban local government (Nekemte) and rural areas of four districts in East Wollega Zone, which is one of the 18 zones of Oromiya regional state, Ethiopia. East Wollega Zone is located at the western part of the country 331 KMs from Addis Ababa, Ethiopia. In the year 2011, the total population of the zone is $1,340,581$ [22]. Oromo is the predominant ethnic group in the zone and Afan Oromo is used as a working language [22].

\section{Study design and population}

A cross-sectional population based household survey was carried out between January and April, 2011. As the source population, ever married/cohabited women aged 15-49 years who were residents of the study community for at least 6 months were used. The aforementioned group was selected as it is at the highest risk of intimate partner violence [14].

Adequate sample size was computed using single proportion sample size calculation formula with the inputs of $95 \%$ confidence level, $4 \%$ margin of error, and $25 \%$ non-response rate [23]. Accordingly, a sample size of 1533 women was calculated. However, to represent the urban and rural distribution, 15\% of the population from urban and $85 \%$ from rural, the sample size was increased to $1600[21,22]$.

Respondents were selected principally using multistage sampling technique. Initially, two from six sub-cities found in Nekemte urban local government and eight kebeles (the lowest administrative unit in the government structure) from four districts at a distance of 20-30 KMs away from the urban to represent the rural community were randomly selected from 50 kebeles. Household census and numbering was done in the selected sub-cities and kebeles to fix a sampling frame. After identifying households with the target groups, proportion to sample size allocations were carried out based on the total number of the selected households they have. Ultimately, systematic random sampling was employed to identify respondents from the selected households as a study unit. In a situation when the household has two or more eligible subjects only one was selected by Kish grid (lottery) method to control the potential intrahousehold correlation [24].

\section{Data collection}

Data was collected by 25 high school completed female interviewers using WHO multi-country study of VAW questionnaire [25]. The questionnaire has been translated to local language (Afan Oromo) by experts in both languages and back translated to English by another person to ensure consistency and accuracy. The data collection process was closely supervised by five Health Officers and principal investigators.

The research team was recruited based on qualification, previous experience in data collection and fluency in local language. Moreover, training was given for seven consecutive days in sampling, interview technique, and ethical issues, emphasizing the importance of safety of the participants and interviewers, minimization of under-reporting and maintaining confidentiality. A pre- 
test study was conducted in one kebeles on $10 \%$ of the total sample size to practically acquaint participants with the administration of interview process.

A standard field work manual developed by WHO for violence study was adopted and used by the research teams [2]. To ensure the quality of the data and minimize inter-interviewer variation, about $5 \%$ of the respondents were re-interviewed at random by principal researchers and supervisors. For that matter few minor differences were detected in the responses given during the second interview.

\section{Measurements}

Variables that have been theoretically, empirically and conceptually linked to IPVAW such as area of residence, age, level of education, occupation, socio-economic status of the household, marital status, alcohol consumption, and husbands fighting habit with another people in the community were taken as independent variables. These and other related variables were categorized into groups where some of them were further sub-divided for bivariate and multivariate analysis.

The dependent variables were considered following conventional definitions of the lifetime and current (past 12 months) experiences of IPVAW. Here, a series of questions were included based on a modified version of the revised Conflict Tactics Scale (CTS2) which guarantees high reliability and constructive validity [26].

The scale lists four questions of psychological abuse to measure items such as insulting the woman, belittlement in front of others, teasing on purpose, and threats to hurt her or someone she cared about. The scale also listed about six questions for physical violence ranking according to its likelihood of causing injuries as moderate like slapping/throwing things, pushing/shoving or severe such as hitting, kicking, beating, choking or burning on purpose, and threatening using a weapon [13]. Additionally, the CTS2 included three questions on sexual violence whether the husbands/partners physically forced to have sexual intercourse when the woman did not want to, or had sexual intercourse when she did not want to because she was afraid of what partner might do, and/or forced to do something sexual that she found humiliating or out of their norms.

\section{Analysis}

The pre-coded responses were double entered into Epi DATA version 3.1 and exported into SPSS version 19 for data checking, cleaning, bivariate and multivariate analysis. Socio-economic status was measured by constructing a wealth index using principal component analysis. Each household was assigned a standardized score that vary depending on whether or not the household owned different assets and the scores were ranked in quintiles [27].

The analysis was focused on the lifetime and current (past 12 months) prevalence of psychological, physical and sexual IPVAW and the association of selected potential socio-demographic, cultural and behavioral factors. Binary logistic regression model was used to identify the characteristics that differentiated ever married/cohabited women who experienced intimate partner violence from those who had not. The results were expressed as crude and adjusted odds ratio relative to the reference category at statistical significance of $95 \%$ confidence intervals and P-value of $<0.05$. The assumptions of logistic regression were checked to be satisfied.

\section{Ethical considerations}

The research was approved for scientific and ethical integrity by institutional review board in the College of Health Sciences, Addis Ababa University. The study strictly followed WHO guideline on ethical issues related to violence research $[2,28,29]$. All interviews took place in a complete privacy. Verbal consent from all respondents and/or assent from respondents aged 15-17 years were secured. During data collection interviewees with serious psychological distress were referred to Nekemte Hospital for counseling. Information regarding available local services was shared to all respondents.

\section{Results}

\section{Socio-demographic characteristics}

A total of 1540 study subjects were attended the interview making a response rate of $96.3 \%$. The socio-demographic characteristics of the women and their partners were described in table 1 . Most of the respondents $(84.2 \%)$ were residing in rural setting and $78.6 \%$ were in the age range of 20-34 years. The mean age of the respondents is 28.4 years $( \pm 5.7 \mathrm{SD})$. The vast majorities (98.7\%) of the respondents were ever married at the time of the interview, predominantly Christian (97.5\%) and Oromo (96.4\%) in their religion and ethnicity.

Nearly about three fifth (59.7\%) of the respondents had no formal education. More than four in every five $(83.3 \%)$ had no job, and $59.5 \%$ moved to the study area due to marriage and work related conditions after born and brought up in other localities where immediate parents were residing.

According to the report from the interviewed respondents, the mean age of the current husbands/partners has been 37.1 years $( \pm 14.5 \mathrm{SD})$. Unlike the respondents, the husbands'/partners' age ranged from 18-88 years. More than one third (34.1\%) of husbands/partners had no formal education, and $67.5 \%$ engaged into agricultural occupations (Table 1). 
Table 1 Socio demographic characteristics of ever married/cohabited women age 15-49 years and their husbands/partners in East Wollega Zone, Western Ethiopia, January to April, 2011

\begin{tabular}{lll}
\hline Characteristics (Variables) $\mathbf{n}=\mathbf{1 5 4 0}$ & Number & Percent \\
\hline Age of respondents & & \\
15-19 years & 28 & 1.8 \\
20-34 years & 1,208 & 78.4 \\
35- 49 years & 304 & 19.8 \\
\hline Marital status & & \\
Currently married & 1420 & 92.2 \\
$\quad$ Currently cohabited & 20 & 1.3 \\
Separated/divorced/widowed & 100 & 6.5 \\
\hline
\end{tabular}

\begin{tabular}{lll}
\hline Education of respondents & \\
No formal education & 919 & 59.7 \\
Primary (1-6 ${ }^{\text {th }}$ grade) & 399 & 25.9 \\
Secondary and above $\left(\geq 7^{\text {th }}\right.$ grade) & 222 & 14.4 \\
\hline Current occupation of respondents & & \\
No job & 1283 & 83.3 \\
Trade activities & 63 & 4.0 \\
Employed into different sectors & 24 & 1.6 \\
Female headed & 74 & 4.8 \\
Housemaid & 25 & 1.6 \\
Others &
\end{tabular}

\begin{tabular}{|c|c|c|}
\hline \multicolumn{3}{|l|}{ Wealth quintile } \\
\hline $\begin{array}{l}\text { Poorest } \\
\text { Poor } \\
\text { Medium } \\
\text { Rich } \\
\text { Richest }\end{array}$ & $\begin{array}{l}305 \\
320 \\
318 \\
269 \\
328\end{array}$ & $\begin{array}{l}19.8 \\
20.8 \\
20.6 \\
17.5 \\
21.3\end{array}$ \\
\hline \multicolumn{3}{|l|}{ Current husbands/partners age } \\
\hline $\begin{array}{l}18-24 \text { years } \\
25-34 \text { years } \\
35-49 \text { years } \\
\geq 50 \text { years }\end{array}$ & $\begin{array}{l}69 \\
669 \\
649 \\
153\end{array}$ & $\begin{array}{l}4.5 \\
43.4 \\
42.1 \\
9.9\end{array}$ \\
\hline \multicolumn{3}{|c|}{ Partner's education level $(n=1529)$} \\
\hline $\begin{array}{l}\text { No formal education } \\
\text { Primary ( } 1-6 \text { grade) } \\
\text { Secondary ( } \geq 7 \text { th grade) }\end{array}$ & $\begin{array}{l}521 \\
559 \\
449\end{array}$ & $\begin{array}{l}34.1 \\
36.6 \\
29.4\end{array}$ \\
\hline \multicolumn{3}{|l|}{ Partner's occupation } \\
\hline $\begin{array}{l}\text { Employee }^{\S} \\
\text { Daily labourer, student } \\
\text { Petty trader } \\
\text { Farmer } \\
\text { No job, retired }\end{array}$ & $\begin{array}{l}146 \\
129 \\
110 \\
1039 \\
116\end{array}$ & $\begin{array}{l}9.5 \\
8.4 \\
7.1 \\
67.5 \\
7.5\end{array}$ \\
\hline
\end{tabular}

Others $^{\dagger}$ include students and unspecified job

Employee $^{\S}$ includes professional, semi skilled, soldiers and police

The larger proportion (63.1\%) of the respondents have got marriage/cohabitation in the age range of 15-19 years, while for $2.3 \%$ of them, the marriage/cohabitation was below the age of 15 years. Accordingly, the mean age of first marriage/cohabitation for the women was 18.6 years $( \pm 2.6 \mathrm{SD})$. On the other hand, $40(2.6 \%)$ of them were divorced when the study was conducted out of which, 17 (42.2\%) of the divorce was decided by husbands/partners, $12(30 \%)$ by the respondents and 10 (25\%) was initiated by both partners.
For about a quarter $(26.3 \%)$ of the couple the initiation of marriage was not based on their own choices. In similar manner, nearly about one in three $(30.1 \%)$ of them have never conducted marriage ceremony when they started to live together. Besides, not surprisingly $7.2 \%$ of the women were reported in having had marriage by abduction. On the other hand, more than one in ten $(12.1 \%)$, two in three $(64.8 \%)$, and more than two in three $(68.4 \%)$ of the respondents had married to polygamous, alcohol drunker, and hostile husbands/partners, in that order (Table 2).

\section{Prevalence and forms of violence}

The occurrences and patterns, timing and frequencies of different forms of IPVAW (psychological, physical, and sexual) were assessed. This is done as the lifetime and current prevalence are useful in reporting the time periods, as recall bias ought to be less in studies of such serious life threatening experiences than inquiring about less sensitive matters [30,31].

\section{Psychological violence}

About two third (66.9\%) of the participating women were verbally insulted and made feel bad about themselves for at least once in their lifetime. One for every three (34.8\%) women was ever humiliated in front of other persons. Moreover, in their lifetime $38.9 \%$ were intimidated, and $18.3 \%$ frightened someone they cared about. In similar manner, for $59.4 \%, 31.5 \%, 6.5 \%$, and $15.5 \%$ of the respondents, these were happened for at least once during the past 12 months, correspondingly. Generally, the prevalence of psychological violence was $70.2 \%$, 95\% CI 67.9-72.5\% during lifetime and 63.9\%, 95\% CI 61.5-66.3\% in current experiences (Table 3).

\section{Physical violence}

Sixty two percent of the respondents ever experienced being slapped and shoved by their husbands/partners across their lifetime. These are the most common acts of moderate physical violence. Most women were reported to have beaten up, punched, dragged and knocked- which are acts of severe physical violence. Other severe acts of physical violence including burning and chocking were also common. In this case, the proportion of women who had experiences of severe physical violence was $54.2 \%$ in lifetime and $49.2 \%$ in past 12 months. This shows that more than three quarter $(79 \%$ not shown) who experienced any physical violence had severe physical aggression in lifetime. Besides, for all cases the violence was exerted as repeated acts as described in table 3. Generally, 1056 (68.6\%, 95\% CI $66.3-70.9 \%)$ of the women experienced at least one or more incidents of physical violence in their lifetime, and 
Table 2 Cultural and behavioral characteristics of ever married/cohabited women aged 15-49 years and their partners in East Wollega Zone, Western Ethiopia, January to April, 2011

\begin{tabular}{|c|c|c|}
\hline Variables & Number & Percent \\
\hline \multicolumn{3}{|l|}{ Age at first marriage/cohabiting $(n=1540)$} \\
\hline $\begin{array}{l}10-14 \text { years } \\
15-19 \text { years } \\
20-24 \text { years } \\
\geq 25 \text { years }\end{array}$ & $\begin{array}{l}36 \\
972 \\
452 \\
58\end{array}$ & $\begin{array}{l}2.3 \\
63.1 \\
29.4 \\
3.8\end{array}$ \\
\hline Mean age at first marriage/cohabited in years $(n=1540)$ & & $2.6 \mathrm{SD}$ \\
\hline \multicolumn{3}{|l|}{ Initiation of marriage/cohabitation $(n=1540)$} \\
\hline $\begin{array}{l}\text { Both (either woman or man) choose } \\
\text { Family and others choose } \\
\text { Abduction }\end{array}$ & $\begin{array}{l}1136 \\
292 \\
112\end{array}$ & $\begin{array}{l}73.8 \\
19.0 \\
7.3\end{array}$ \\
\hline \multicolumn{3}{|l|}{ Marriage ceremony $(n=1540)$} \\
\hline $\begin{array}{l}\text { None } \\
\text { Civil marriage } \\
\text { Religious marriage } \\
\text { Customary marriage }\end{array}$ & $\begin{array}{l}463 \\
63 \\
390 \\
624\end{array}$ & $\begin{array}{l}30.1 \\
4.1 \\
25.3 \\
40.5\end{array}$ \\
\hline \multicolumn{3}{|l|}{ Initiation of divorce $(n=40)$} \\
\hline $\begin{array}{l}\text { Respondent } \\
\text { Husband/partner } \\
\text { Both (respondent and partner) } \\
\text { Family }\end{array}$ & $\begin{array}{l}12 \\
17 \\
10 \\
1\end{array}$ & $\begin{array}{l}30.0 \\
42.5 \\
25.0 \\
2.5\end{array}$ \\
\hline \multicolumn{3}{|l|}{ Number of children $(n=1540)$} \\
\hline $\begin{array}{l}0 \\
1-2 \\
\geq 3\end{array}$ & $\begin{array}{l}70 \\
626 \\
844\end{array}$ & $\begin{array}{l}4.5 \\
40.6 \\
54.8\end{array}$ \\
\hline \multicolumn{3}{|l|}{ Respondent drink alcohol $(n=1539)$} \\
\hline $\begin{array}{l}\text { Never } \\
\text { Light (occasional) } \\
\text { Heavy (frequently) }\end{array}$ & $\begin{array}{l}681 \\
554 \\
304\end{array}$ & $\begin{array}{l}44.2 \\
36.0 \\
19.8\end{array}$ \\
\hline \multicolumn{3}{|l|}{ Situation of marriage for current husbands/partners $(n=1540)$} \\
\hline $\begin{array}{l}\text { Monogamous } \\
\text { Polygamous } \\
\text { Refused to answer } \\
\end{array}$ & $\begin{array}{l}1351 \\
186 \\
3\end{array}$ & $\begin{array}{l}87.7 \\
12.1 \\
0.2\end{array}$ \\
\hline \multicolumn{3}{|l|}{ Partner's drink alcohol $(n=1512)$} \\
\hline $\begin{array}{l}\text { Never } \\
\text { Light (occasional) } \\
\text { Heavy (frequently) }\end{array}$ & $\begin{array}{l}532 \\
493 \\
487\end{array}$ & $\begin{array}{l}35.2 \\
32.6 \\
32.2\end{array}$ \\
\hline \multicolumn{3}{|l|}{ Husbands/partners fighting habit $(n=1503)$} \\
\hline $\begin{array}{l}\text { No } \\
\text { Yes }\end{array}$ & $\begin{array}{l}449 \\
1054\end{array}$ & $\begin{array}{l}29.2 \\
68.4\end{array}$ \\
\hline
\end{tabular}

for 964 (62.6\%, 95 CI 60.2-65.0\%) the incidents were happened during the past 12 months.

\section{Sexual violence}

About $59 \%$ of the respondents reported that at some point in their life time, their husbands/partners had forced them to have sexual intercourse without their interest or consent and in $51 \%$ of them it was happened in the preceding 12 months of the survey. In addition, $46.2 \%$ and $40.4 \%$ of respondents experienced sexual intercourse during their lifetime and current relationship due to fear of their husbands/partners. The proportion of women who had been forced into a humiliating sexual acts like pornographic show or practice of sexual acts out of their norms were $8.3 \%$ and $7.0 \%$ during lifetime and past 12 months, respectively. Overall, 948 (61.6\%, 95\% CI 59.2-64.0\%) and 847 (55.0\%, 95\% CI $52.5-57.5 \%)$ of the women have reported to have at least one incident of sexual violence in their lifetime and past 12 months, respectively.

\section{Prevalence and patterns of IPVAW-summary measures} In this study, 1178 (76.5\%, 95\% CI 74.4-78.6\%) of the respondents experienced IPVAW in one form or another at some point in their lifetime. Besides, 1117 (72.5\%, 95\% CI 70.3-74.7\%) of them experienced the same incidents in the past 12 months. Most acts of IPVAW were part and a pattern of continuing abuse 
Table 3 Life time and past 12 months prevalence and frequency of different forms of IPVAW among ever married/ cohabited women age 15-49 years in East Wollega Zone, Western Ethiopia, January to April, 2011

\begin{tabular}{|c|c|c|c|c|c|c|c|c|}
\hline \multirow[t]{2}{*}{ Forms of IPVAW $(\mathrm{N}=1540)$} & \multirow{2}{*}{$\begin{array}{c}\text { Lifetime } \\
\begin{array}{c}\text { Number } \\
\%\end{array}\end{array}$} & \multirow{2}{*}{$\begin{array}{c}\begin{array}{c}\text { Past } 12 \\
\text { months }\end{array} \\
\text { Number \% }\end{array}$} & \multicolumn{3}{|c|}{$\begin{array}{l}\text { Frequency in the current (past } 12 \\
\text { months) }\end{array}$} & \multicolumn{3}{|c|}{ Frequency before 12 months } \\
\hline & & & Once & $\begin{array}{c}\text { Few times } \\
\text { '(2-5) }\end{array}$ & $\begin{array}{l}\text { Many times } \\
\quad(>5)\end{array}$ & Once & $\begin{array}{c}\text { Few times } \\
(2-5)\end{array}$ & $\begin{array}{l}\text { Many times } \\
(>5)\end{array}$ \\
\hline \multicolumn{9}{|l|}{ Psychological/Emotional violence } \\
\hline • Insulted/made feel bad & $\begin{array}{l}1,030 \\
(66.9)\end{array}$ & $914(59.4)$ & $\begin{array}{l}230 \\
(24.9)\end{array}$ & $565(36.7)$ & $119(7.7)$ & $\begin{array}{c}207 \\
(13.4)\end{array}$ & $539(35.0)$ & $278(18.1)$ \\
\hline - Humiliated in front of others & $\begin{array}{c}536 \\
(34.8)\end{array}$ & $485(31.5)$ & $\begin{array}{l}190 \\
(12.3)\end{array}$ & $219(14.2)$ & $76(4.9)$ & $\begin{array}{l}113 \\
(7.3)\end{array}$ & $303(19.7)$ & $120(7.8)$ \\
\hline - Intimidated on purpose & $\begin{array}{c}599 \\
(38.9)\end{array}$ & $524(6.5)$ & $\begin{array}{l}190 \\
(12.3)\end{array}$ & $271(17.6)$ & $64(4.2)$ & $\begin{array}{l}134 \\
(8.7)\end{array}$ & $327(21.2)$ & $131(8.5)$ \\
\hline $\begin{array}{l}\text { - Threaten/hurt/frighten someone they } \\
\text { care about }\end{array}$ & $\begin{array}{l}281 \\
(18.3)\end{array}$ & $242(15.7)$ & $\begin{array}{l}114 \\
(7.4)\end{array}$ & $96(6.2)$ & $32(2.1)$ & $79(5.1)$ & $143(9.3)$ & $56(3.6)$ \\
\hline $\begin{array}{l}\text { At least one episode of } \\
\text { psychological abuse }\end{array}$ & $\begin{array}{c}1081 \\
(70.2) \\
\end{array}$ & $984(63.9)$ & $\begin{array}{c}394 \\
(25.6) \\
\end{array}$ & $680(44.2)$ & $207(13.4)$ & $\begin{array}{c}300 \\
(19.5) \\
\end{array}$ & $746(48.4)$ & $366(23.8)$ \\
\hline \multicolumn{9}{|l|}{ Physical violence } \\
\hline Moderate physical violence & $\begin{array}{c}961 \\
(62.4)\end{array}$ & $961(62.3)$ & $\begin{array}{c}288 \\
(18.7)\end{array}$ & $595(38.6)$ & $118(7.7)$ & $\begin{array}{l}237 \\
(15.4)\end{array}$ & $631(41.0)$ & $262(17.0)$ \\
\hline - Slapped/Thrown some thing & $\begin{array}{l}893 \\
(58.0)\end{array}$ & $797(51.6)$ & $\begin{array}{l}222 \\
(14.4)\end{array}$ & $495(32.1)$ & $78(5.1)$ & $\begin{array}{c}179 \\
(11.6)\end{array}$ & $511(33.2)$ & $200(13.0)$ \\
\hline - Pushed or shoved & $\begin{array}{c}621 \\
(40.3)\end{array}$ & $540(35.1)$ & $\begin{array}{c}159 \\
(10.3)\end{array}$ & $32421.0)$ & $59(3.8)$ & $\begin{array}{l}145 \\
(9.4)\end{array}$ & $371(24.1)$ & $108(7.0)$ \\
\hline$\underline{\text { Sever physical violence }}$ & $\begin{array}{c}835 \\
(54.2)\end{array}$ & $757(49.2)$ & $\begin{array}{c}230 \\
(14.9)\end{array}$ & $521(33.8)$ & $82(5.3)$ & $\begin{array}{c}161 \\
(10.5)\end{array}$ & $517(33.6)$ & $266(17.3)$ \\
\hline - Hit with fist or something else & $\begin{array}{c}649 \\
(42.1)\end{array}$ & $581(37.7)$ & $\begin{array}{c}164 \\
(10.6)\end{array}$ & $375(24.4)$ & $42(2.7)$ & $\begin{array}{l}110 \\
(7.1)\end{array}$ & $367(23.8)$ & $170(11.0)$ \\
\hline - Kicked, dragged or beat & $\begin{array}{c}570 \\
(37.0)\end{array}$ & $490(31.8)$ & $97(6.3)$ & $338(21.9)$ & $57(3.7)$ & $66(4.3)$ & $305(19.8)$ & $193(12.5)$ \\
\hline - Choked or burnt & $142(9.2)$ & $125(8.1)$ & $39(2.5)$ & $76(4.9)$ & $9(0.6)$ & $21(1.4)$ & 103(6.7) & $23(1.5)$ \\
\hline $\begin{array}{c}\text { - Threatened or used weapon (gun, } \\
\text { knife) }\end{array}$ & $86(5.6)$ & $80(5.2)$ & $27(1.8)$ & $47(3.1)$ & $7(0.5)$ & $16(1.0)$ & $55(3.6)$ & $23(1.5)$ \\
\hline $\begin{array}{l}* \text { At least one episode of physical } \\
\text { violence }\end{array}$ & $\begin{array}{r}1056 \\
(68.6)\end{array}$ & $964(62.6)$ & $\begin{array}{c}379 \\
(24.6)\end{array}$ & 749 (48.6) & $160(10.4)$ & $\begin{array}{c}290 \\
(18.8)\end{array}$ & $769(49.9)$ & $388(25.2)$ \\
\hline \multicolumn{9}{|l|}{ Sexual violence } \\
\hline - Physically forced to have sex & $\begin{array}{c}904 \\
(58.7)\end{array}$ & $786(51.0)$ & $\begin{array}{c}160 \\
(10.4)\end{array}$ & $417(27.1)$ & 208(13.5) & $\begin{array}{l}126 \\
(8.2)\end{array}$ & $432(28.1)$ & $333(21.6)$ \\
\hline - Having sex because of fear of partner & $\begin{array}{c}712 \\
(46.2)\end{array}$ & $622(40.4)$ & $\begin{array}{l}116 \\
(7.5)\end{array}$ & $317(20.6)$ & 199 (12.9) & $\begin{array}{l}105 \\
(6.8)\end{array}$ & $319(20.7)$ & $282(18.3)$ \\
\hline - Sex that is degrading/humiliating & $127(8.3)$ & $108(7.0)$ & $29(1.9)$ & $70(4.5)$ & $10(0.6)$ & $26(1.7)$ & $79(5.1)$ & $24(1.6)$ \\
\hline $\begin{array}{l}* \text { At least one episode of sexual } \\
\text { violence }\end{array}$ & $\begin{array}{c}948 \\
(61.6)\end{array}$ & $847(55.0)$ & $\begin{array}{c}204 \\
(13.2)\end{array}$ & $500(32.5)$ & $250(16.2)$ & $\begin{array}{c}165 \\
(10.7)\end{array}$ & $499(32.4)$ & $394(25.6)$ \\
\hline At least one of the three violence & $\begin{array}{c}1178 \\
(76.5)\end{array}$ & $1117(72.5)$ & & & & & & \\
\hline
\end{tabular}

NB- Percentage in each column may not add 100 as respondents can report more than one

rather than being an isolated event (for detail, Table $3)$.

Although it is expected that the overall prevalence of IPVAW in the past 12 months would be substantially lower than the women's lifetime experiences, much smaller variation with similar patterns were observed (Table 3). Likewise, most respondents experienced each act of IPVAW from once to many times in lifetime and past 12 months.

The proportion of respondents experienced the three forms of IPVAW during current (past 12 months), previous (before one year), and lifetime marital or cohabiting relationship indicated that out of $76.5 \%$ who had gone through lifetime IPVAW, about $75.8 \%$ had the incident in the previous and $72.5 \%$ in the past 12 months. Similarly, the patterns were $70.2 \%, 70.0 \%$ and $63.9 \%$ for psychological violence, $68.6 \%, 68.6 \%$ and $62.2 \%$ for physical, and $61.6 \%, 61.0 \%$ and $55.0 \%$ for sexual violence. These patterns revealed, the percentage of current, previous, and lifetime experiences of IPVAW are almost similar.

The patterns for the joint occurrences of different forms of IPVAW are shown in figure 1. Hence, physical 


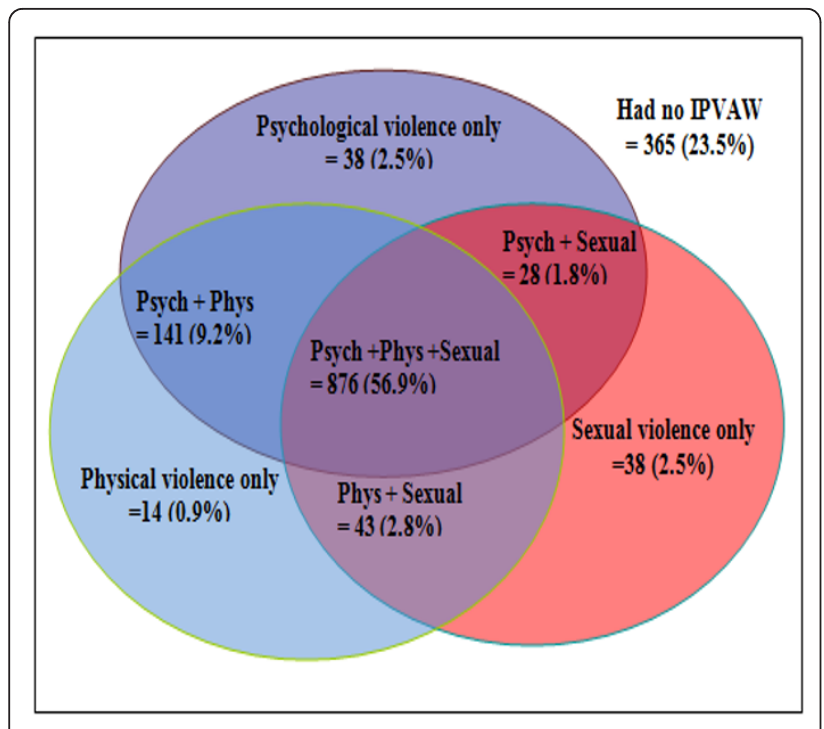

Figure 1 Venn diagram illustrating overlaps between lifetime experiences of psychological, physical and sexual violence reported by ever married/cohabited women aged 15-49 years in East Wollega Zone, Western Ethiopia, January to April, 2011

violence $(0.9 \%)$ is less likely to occur in isolated form when compared to psychological and sexual violence which accounts $2.5 \%$ for each of the isolated occurrence. However, the joint occurrences of psychological and physical violence account $9.2 \%$. It exceeds the other two overlapping patterns of $1.8 \%$ and $2.8 \%$ for psychological + sexual violence and of physical + sexual violence, respectively. On the other hand, the greater proportion (56.9\%) of women experienced multiple forms of violence from their intimate partners at the same time.

\section{Factors associated with IPVAW}

In the final model, a number of socio-demographic factors were identified as significant predictors of lifetime and current experiences of IPVAW (Table 4). Compared to urban dwellers, rural dwellers were less likely to report lifetime IPVAW (AOR 0.58, 95\% CI 0.34-0.98). However, this association was not significant after controlling for other factors in past 12 months. In the same way, compared to respondents aged 15-19 years, those from 35-49 years were about four times (AOR 3.36, 95\% CI 1.27-8.89) and three times (AOR 2.75, 95\% CI 1.106.86) more likely to report lifetime and current IPVAW.

On the other hand, the protective effects of education for both women as victim and men as perpetrator were found to be significant in the lifetime and current experiences of IPVAW after controlling for age, occupation and socio-economic statuses. However, those women who have equal educational statuses with their husbands/partners were (AOR 1.67, 95\% CI 1.05-2.68) more likely to report current experiences of IPVAW than women with greater educational status of their husbands/partners. This association was also noteworthy in lifetime experiences of IPVAW before adjusting for the variables in the model. Similarly, female headed respondents engaged into different working condition were (AOR 0.46, 95\% CI 0.27-0.76) less likely to report lifetime IPVAW compared to jobless women.

Compared to respondents from the poorest household, those respondents from poor (AOR 0.65, 95\% CI 0.44-0.97), the richer (AOR 0.61, 95\% CI 0.40-0.94), and the richest households were (AOR 0.66, 95\% CI 0.440.99) less likely to report lifetime IPVAW. Similarly, these associations were found significant for current experiences of IPVAW (Table 4).

Table 5 presents the association of cultural and behavioral factors with IPVAW. It shows that women married/cohabited by abduction (AOR 3.71, 95\% CI 1.0113.63), to polygamous partners (AOR 3.79, 95\% CI 1.648.73 ), to heavy alcohol drunkard (AOR 1.98, 95\% CI 1.21-3.22), and to hostile partners (AOR 3.96, 95\% CI 2.52-6.20) remained associated with increased experiences of lifetime IPVAW. These were also found significant in the past 12 months experiences of IPVAW.

In addition, compared to women who got married/ cohabited at the age of 10-14 years, those who had at 15-19 years (AOR 3.41, 95\% CI 1.31-8.89), 20-24 years (AOR 2.93, 95\% CI 1.10-7.78), and $\geq 25$ years were (AOR 4.26, 95\% CI 1.27-14.2) more likely to report past 12 months experiences of IPVAW.

Furthermore, respondents were also asked whether their fore mothers were hit by fore fathers/husbands when they were children. Accordingly, witnessing interparental violence as a child were twice (AOR 2.00, 95\% CI 1.54-2.56), and more than one and half times (AOR 1.66, 95\% CI 1.17-2.37) more likely to report lifetime and current IPVAW, respectively. Also respondents whose husbands/partners themselves beaten by someone in their family during their childhood were nearly two times (AOR 1.89, 95\% CI 1.17-3.03), and more than twice (AOR 2.11, 95\% CI 1.41-3.15) as likely to report lifetime and current experiences of IPVAW (Table 5).

\section{Discussion}

The objective of this study was to investigate the extent, patterns and associated factors of intimate partner violence against women. Most data on the prevalence of intimate partner violence comes from cross-sectional population based surveys [32]. Prevalence figures are liable to under or over reporting as the issue is surrounded by taboo and stigma [33,34].

The overall prevalence of IPVAW in this study is greater than any studies elsewhere $[2,13,14]$, including studies from other parts of Ethiopia [17-21,35]. For instance, the findings from Butajira, Ethiopia, showed 
Table 4 Odds Ratios predicting IPVAW among ever married/cohabited women aged 15-49 by selected socio-demographic variables in East Wollega Zone, Western Ethiopia, January to April, 2011

\begin{tabular}{|c|c|c|c|c|c|c|}
\hline \multirow[t]{2}{*}{ Variables } & \multicolumn{3}{|c|}{ Lifetime IPVAW } & \multicolumn{3}{|c|}{ Recent (past 12 months) IPVAW } \\
\hline & № (\%) & COR $(95 \% \mathrm{Cl})$ & AOR $(95 \% \mathrm{Cl})$ & №ᅳ (\%) & COR $(95 \% \mathrm{Cl})$ & AOR $(95 \% \mathrm{Cl})$ \\
\hline \multicolumn{7}{|l|}{ Residence } \\
\hline Urban & $214(87.7)$ & 1.00 & 1.00 & $17(80.3)$ & 1.00 & 1.00 \\
\hline Rural & $965(74.4)$ & $\begin{array}{l}0.41 \text { (0.27 to } 0.61) \\
* *\end{array}$ & $0.58(0.34 \text { to } 0.98)^{*}$ & $33(71.1)$ & $0.60(0.43 \text { to } 0.84)^{*}$ & $0.92(0.58$ to 1.47$)$ \\
\hline \multicolumn{7}{|l|}{ Age of respondent } \\
\hline 15-19 years & $18(64.3)$ & 1.00 & 1.00 & $18(64.3)$ & 1.00 & 1.00 \\
\hline 20-34 years & $901(74.5)$ & $1.62(0.74$ to 3.56$)$ & $1.56(0.63$ to 3.85$)$ & $850(70.4)$ & $1.35(1.02 \text { to } 1.78)^{*}$ & 1.25 (0.54 to 2.91$)$ \\
\hline $35-49$ years & $260(85.5)$ & $\begin{array}{l}3.28 \text { (1.42 to } 7.58) \\
*\end{array}$ & $3.36(1.27 \text { to } 8.89)^{*}$ & $249(81.9)$ & $1.38(1.02 \text { to } 1.86)^{*}$ & $\begin{array}{l}2.75 \text { (1.10 to } 6.86) \\
\text { ( }\end{array}$ \\
\hline \multicolumn{7}{|l|}{ Relationship with current partner } \\
\hline Currently married & $1079(76.0)$ & 1.00 & 1.00 & $1026(72.3)$ & 1.00 & - - \\
\hline Currently cohabited & $14(70.0)$ & 0.74 (0.28 to 1.93$)$ & 0.81 (0.27 to 2.44$)$ & $12(60.0)$ & $0.58(0.23$ to 1.42$)$ & \\
\hline Divorced, separated, widowed & $85(85.0)$ & $\begin{array}{l}1.79(1.02 \text { to } 3.14) \\
*\end{array}$ & 1.64 (0.87 to 3.10$)$ & 79 (79.0) & $1.45(0.88$ to 2.37$)$ & \\
\hline \multicolumn{7}{|l|}{ Education level of respondents } \\
\hline No formal education & $710(77.3)$ & 1.00 & 1.00 & $22(74.3)$ & 1.00 & 1.00 \\
\hline Primary (1-6 grade) & $289(72.4)$ & $0.82(0.57$ to 1.18$)$ & $0.65(0.48 \text { to } 0.88)^{*}$ & $16(67.2)$ & $0.71(0.55 \text { to } 0.91)^{*}$ & $\begin{array}{l}0.63 \text { (0.48 to } 0.84) \\
\text { ( }\end{array}$ \\
\hline Secondary and above $(\geq 7)$ & $180(80.6)$ & $\begin{array}{l}0.63(0.42 \text { to } 0.94) \\
*\end{array}$ & $0.72(0.45$ to 1.17$)$ & $22(74.8)$ & $1.02(0.73$ to 1.44$)$ & 0.71 (0.46 to 1.10$)$ \\
\hline \multicolumn{7}{|l|}{ Occupation of respondents } \\
\hline No job & $1020(76.8)$ & 1.00 & 1.00 & $963(72.5)$ & 1.00 & 1.00 \\
\hline Student/employee/trader & $90(79.6)$ & $1.18(0.74$ to 1.90$)$ & $\begin{array}{l}0.87 \text { ( } 0.50 \text { to } 1.52) 5.29 \text { ( } 0.66 \text { to } \\
42.69 \text { ) }\end{array}$ & $87(77.0)$ & 1.27 (0.81 to 2.00$)$ & $1.18(0.71$ to 1.97$)$ \\
\hline Housemaid & $24(96.0)$ & 7.25 (0.98 to 53.79$)$ & $0.46(0.27 \text { to } 0.76)^{*}$ & $23(92.0)$ & $\begin{array}{l}4.36(1.02 \text { to } \\
18.58)^{*}\end{array}$ & 3.99 (0.87 to 18.37$)$ \\
\hline Farmers (female headed) & $44(59.5)$ & $\begin{array}{l}0.44 \text { (0.27 to } 0.72) \\
*\end{array}$ & & $44(59.5)$ & $0.56(0.34 \text { to } 0.90)^{*}$ & 0.58 (0.35 to 0.97$)$ \\
\hline \multicolumn{7}{|l|}{ Partner's education level } \\
\hline No formal education & $413(79.3)$ & 1.00 & 1.00 & $394(75.6)$ & 1.00 & 1.00 \\
\hline Primary (1-6 grade) & $411(73.5)$ & $0.73(0.55 \text { to } 0.96)^{*}$ & $0.73(0.55 \text { to } 0.99)^{*}$ & $393(70.3)$ & $0.76(0.58 \text { to } 1.00)^{*}$ & 0.73 (0.59 to 1.04$)$ \\
\hline Secondary and above $(\geq 7)$ & $344(76.6)$ & 0.86 (0.63 to 1.16$)$ & 0.74 (0.43 to 1.29$)$ & $320(71.3)$ & $0.80(0.60$ to 1.04$)$ & $\begin{array}{l}0.71(0.51 \text { to } 0.98) \\
*\end{array}$ \\
\hline \multicolumn{7}{|l|}{$\begin{array}{l}\text { Difference of education between } \\
\text { partners }\end{array}$} \\
\hline Women higher & $110(71.7)$ & 1.00 & 1.00 & $10065.8)$ & 1.00 & 1.00 \\
\hline Equal educational status & $496(79.7)$ & $\begin{array}{l}1.55 \text { (1.04 to } 2.33 \text { ) } \\
*\end{array}$ & 1.63 (0.97 to 2.73$)$ & $470(75.6)$ & $1.61(1.20 \text { to } 2.36)^{*}$ & ${ }_{*} .67$ (1.05 to 2.68 ) \\
\hline
\end{tabular}


Table 4 Odds Ratios predicting IPVAW among ever married/cohabited women aged 15-49 by selected socio-demographic variables in East Wollega Zone, Western Ethiopia, January to April, 2011 (Continued)

\begin{tabular}{|c|c|c|c|c|c|c|}
\hline Woman's lower & $563(74.6)$ & $1.16(0.78$ to 1.71$)$ & $1.36(0.67$ to 2.76$)$ & $537(71.1)$ & $1.28(0.86$ to 1.86$)$ & $1.44(0.76$ to 2.76$)$ \\
\hline \multicolumn{7}{|l|}{ Age of current husbands/partners } \\
\hline $18-29$ years & $250(71.5)$ & 1.00 & 1.00 & $250(67.8)$ & 1.00 & 1.00 \\
\hline 30-39 years & $532(77.5)$ & $\begin{array}{l}1.37 \text { (1.03 to } 1.82 \text { ) } \\
*\end{array}$ & $1.06(0.77$ to 1.44$)$ & $532(73.9)$ & $1.35(1.02 \text { to } 1.77)^{*}$ & $1.12(0.84$ to 1.51$)$ \\
\hline$\geq 40$ years & $335(78.9)$ & $\begin{array}{l}1.49 \text { (1.08 to } 2.05) \\
*\end{array}$ & 0.80 (0.53 to 1.17$)$ & $335(74.3)$ & $1.38(1.02 \text { to } 1.86)^{*}$ & 0.84 (0.59 to 1.20$)$ \\
\hline Partners occupation & & & & & & -— \\
\hline Employeet & $120(82.2)$ & 1.00 & 1.00 & $112(76.7)$ & 1.00 & \\
\hline Daily labourer, student & $104(80.6)$ & 0.90 (0.49 to 1.66$)$ & 0.88 (0.46 to 1.68$)$ & $98(76.0)$ & 0.96 (0.55 to 1.68$)$ & \\
\hline Petty trader & $91(82.7)$ & 1.04 (0.54 to 1.99$)$ & $1.41(0.50$ to 2.83$)$ & $82(74.5)$ & $0.89(0.50$ to 1.58$)$ & \\
\hline Farmer & $767(73.7)$ & $\begin{array}{l}0.61 \text { (0.39 to } 0.95) \\
*\end{array}$ & 0.75 (0.43 to 1.29$)$ & 734 (70.6) & 0.73 (0.49 to 1.10$)$ & \\
\hline No job, retired & 97 (83.6) & 1.11 (0.58 to 2.12 ) & 1.11 (0.56 to 2.18$)$ & $91(78.4)$ & $1.12(0.62$ to 1.99$)$ & \\
\hline \multicolumn{7}{|l|}{ Wealth quintile } \\
\hline Poorest & $250(82.0)$ & 1.00 & 1.00 & $239(78.4)$ & 1.00 & 1.00 \\
\hline Poor & $239(74.7)$ & $\begin{array}{l}0.65 \text { (0.44 to } 0.96) \\
*\end{array}$ & $0.64(0.43 \text { to } 0.96)^{*}$ & $228(71.3)$ & $0.68(0.48 \text { to } 0.99)^{*}$ & 0.70 (0.48 to 1.02$)$ \\
\hline Medium & $241(75.8)$ & 0.69 (0.47 to 1.02$)$ & 0.71 (0.47 to 1.07$)$ & $228(71.7)$ & $0.70(0.49$ to 1.01$)$ & $0.76(0.52$ to 1.11$)$ \\
\hline Richer & $197(73.2)$ & $\begin{array}{l}0.60 \text { (0.40 to } 0.90) \\
*\end{array}$ & $0.61(0.40 \text { to } 0.94)^{*}$ & $186(69.1)$ & $0.62(0.43 \text { to } 0.90)^{*}$ & $\underset{*}{0.65}$ (0.44 to 0.97$)$ \\
\hline Richest & $251(76.5)$ & $0.72(0.49$ to 1.06$)$ & $0.66(0.44 \text { to } 0.99)^{*}$ & $236(72.0)$ & 0.71 (0.49 to 1.02$)$ & 0.69 (0.47 to.02) \\
\hline \multirow[t]{2}{*}{ Variables } & $\begin{array}{l}\text { Lifetime } \\
\text { IPVAW }\end{array}$ & & & $\begin{array}{c}\text { Recent (past } 12 \text { months) } \\
\text { IPVAW }\end{array}$ & & \\
\hline & No (\%) & COR $(95 \% \mathrm{Cl})$ & AOR $(95 \% \mathrm{CI})$ & No (\%) & COR $(95 \% \mathrm{Cl})$ & AOR $(95 \% \mathrm{Cl})$ \\
\hline \multicolumn{7}{|l|}{ Residence } \\
\hline Urban & $214(87.7)$ & 1.00 & 1.00 & $17(80.3)$ & 1.00 & 1.00 \\
\hline Rural & $965(74.4)$ & $\begin{array}{l}0.41 \\
* *\end{array}$ & $0.58(0.34 \text { to } 0.98)^{*}$ & $33(71.1)$ & $0.60(0.43 \text { to } 0.84)^{*}$ & $0.92(0.58$ to 1.47$)$ \\
\hline \multicolumn{7}{|l|}{ Age of respondent } \\
\hline 15-19 years & $18(64.3)$ & 1.00 & 1.00 & $18(64.3)$ & 1.00 & 1.00 \\
\hline $20-34$ years & $901(74.5)$ & $1.62(0.74$ to 3.56$)$ & $1.56(0.63$ to 3.85$)$ & $850(70.4)$ & $1.35(1.02 \text { to } 1.78)^{*}$ & $1.25(0.54$ to 2.91$)$ \\
\hline 35- 49 years & $260(85.5)$ & $\begin{array}{l}3.28 \text { (1.42 to } 7.58) \\
*\end{array}$ & $3.36(1.27 \text { to } 8.89)^{*}$ & $249(81.9)$ & $1.38(1.02 \text { to } 1.86)^{*}$ & 2.75 (1.10 to 6.86$)$ \\
\hline \multicolumn{7}{|l|}{ Relationship with current partner } \\
\hline Currently married & $1079(76.0)$ & 1.00 & 1.00 & $1026(72.3)$ & 1.00 & -— \\
\hline Currently cohabited & $14(70.0)$ & 0.74 (0.28 to 1.93$)$ & 0.81 (0.27 to 2.44$)$ & $12(60.0)$ & 0.58 (0.23 to 1.42$)$ & \\
\hline Divorced, separated, widowed & $85(85.0)$ & $\begin{array}{l}1.79 \text { (1.02 to } 3.14) \\
*\end{array}$ & 1.64 (0.87 to 3.10$)$ & $79(79.0)$ & 1.45 (0.88 to 2.37$)$ & \\
\hline
\end{tabular}


Table 4 Odds Ratios predicting IPVAW among ever married/cohabited women aged 15-49 by selected socio-demographic variables in East Wollega Zone, Western Ethiopia, January to April, 2011 (Continued)

\begin{tabular}{|c|c|c|c|c|c|c|}
\hline \multicolumn{7}{|l|}{ Education level of respondents } \\
\hline No formal education & $710(77.3)$ & 1.00 & 1.00 & $22(74.3)$ & 1.00 & 1.00 \\
\hline Primary (1-6 grade) & $289(72.4)$ & $0.82(0.57$ to 1.18$)$ & $0.65(0.48 \text { to } 0.88)^{*}$ & $16(67.2)$ & $0.71(0.55 \text { to } 0.91)^{*}$ & $\underset{*}{0.63}$ (0.48 to 0.84$)$ \\
\hline Secondary and above $(\geq 7)$ & $180(80.6)$ & $\begin{array}{l}0.63 \text { (0.42 to } 0.94) \\
*\end{array}$ & $0.72(0.45$ to 1.17$)$ & $22(74.8)$ & $1.02(0.73$ to 1.44$)$ & $0.71(0.46$ to 1.10$)$ \\
\hline \multicolumn{7}{|l|}{ Occupation of respondents } \\
\hline No job & $1020(76.8)$ & 1.00 & 1.00 & $963(72.5)$ & 1.00 & 1.00 \\
\hline Student/employee/trader & $90(79.6)$ & $1.18(0.74$ to 1.90$)$ & $\begin{array}{l}0.87 \text { (0.50 to } 1.52) 5.29 \text { (0.66 to } \\
42.69)\end{array}$ & $87(77.0)$ & 1.27 (0.81 to 2.00$)$ & $1.18(0.71$ to 1.97$)$ \\
\hline Housemaid & $24(96.0)$ & 7.25 (0.98 to 53.79) & $0.46(0.27 \text { to } 0.76)^{*}$ & $23(92.0)$ & $\begin{array}{l}4.36(1.02 \text { to } \\
18.58)^{*}\end{array}$ & 3.99 (0.87 to 18.37$)$ \\
\hline Farmers (female headed) & $44(59.5)$ & $\begin{array}{l}0.44 \text { (0.27 to } 0.72) \\
*\end{array}$ & & $44(59.5)$ & $0.56(0.34 \text { to } 0.90)^{*}$ & $0.58(0.35$ to 0.97$)$ \\
\hline \multicolumn{7}{|l|}{ Partner's education level } \\
\hline No formal education & $413(79.3)$ & 1.00 & 1.00 & $394(75.6)$ & 1.00 & 1.00 \\
\hline Primary (1-6 grade) & $411(73.5)$ & $0.73(0.55 \text { to } 0.96)^{*}$ & $0.73(0.55 \text { to } 0.99)^{*}$ & $393(70.3)$ & $0.76(0.58 \text { to } 1.00)^{*}$ & $0.73(0.59$ to 1.04$)$ \\
\hline Secondary and above $(\geq 7)$ & $344(76.6)$ & 0.86 (0.63 to 1.16$)$ & 0.74 (0.43 to 1.29$)$ & $320(71.3)$ & $0.80(0.60$ to 1.04$)$ & $0.71(0.51$ to 0.98$)$ \\
\hline \multicolumn{7}{|l|}{$\begin{array}{l}\text { Difference of education between } \\
\text { partners }\end{array}$} \\
\hline Women higher & $110(71.7)$ & 1.00 & 1.00 & $10065.8)$ & 1.00 & 1.00 \\
\hline Equal educational status & $496(79.7)$ & $\begin{array}{l}1.55 \text { (1.04 to } 2.33) \\
*\end{array}$ & $1.63(0.97$ to 2.73$)$ & $470(75.6)$ & $1.61(1.20 \text { to } 2.36)^{*}$ & $\begin{array}{l}1.67 \text { (1.05 to } 2.68) \\
*\end{array}$ \\
\hline Woman's lower & $563(74.6)$ & 1.16 (0.78 to 1.71$)$ & 1.36 (0.67 to 2.76$)$ & $537(71.1)$ & $1.28(0.86$ to 1.86$)$ & $1.44(0.76$ to 2.76$)$ \\
\hline \multicolumn{7}{|c|}{ Age of current husbands/partners } \\
\hline $18-29$ years & $250(71.5)$ & 1.00 & 1.00 & $250(67.8)$ & 1.00 & 1.00 \\
\hline $30-39$ years & $532(77.5)$ & $\begin{array}{l}1.37 \text { (1.03 to } 1.82) \\
*\end{array}$ & 1.06 (0.77 to 1.44$)$ & $532(73.9)$ & $1.35(1.02 \text { to } 1.77)^{*}$ & $1.12(0.84$ to 1.51$)$ \\
\hline$\geq 40$ years & $335(78.9)$ & $\begin{array}{l}1.49 \text { (1.08 to } 2.05) \\
*\end{array}$ & $0.80(0.53$ to 1.17$)$ & $335(74.3)$ & $1.38(1.02 \text { to } 1.86)^{*}$ & $0.84(0.59$ to 1.20$)$ \\
\hline Partners occupation & & & & & & -- \\
\hline Employeet & $120(82.2)$ & 1.00 & 1.00 & $112(76.7)$ & 1.00 & \\
\hline Daily labourer, student & $104(80.6)$ & 0.90 (0.49 to 1.66$)$ & 0.88 (0.46 to 1.68$)$ & $98(76.0)$ & 0.96 (0.55 to 1.68$)$ & \\
\hline Petty trader & $91(82.7)$ & 1.04 (0.54 to 1.99$)$ & 1.41 (0.50 to 2.83$)$ & $82(74.5)$ & 0.89 (0.50 to 1.58$)$ & \\
\hline Farmer & $767(73.7)$ & $\begin{array}{l}0.61 \text { (0.39 to } 0.95) \\
*\end{array}$ & 0.75 (0.43 to 1.29$)$ & $734(70.6)$ & $0.73(0.49$ to 1.10$)$ & \\
\hline No job, retired & 97 (83.6) & 1.11 (0.58 to 2.12 ) & 1.11 (0.56 to 2.18$)$ & $91(78.4)$ & $1.12(0.62$ to 1.99$)$ & \\
\hline \multicolumn{7}{|l|}{ Wealth quintile } \\
\hline Poorest & $250(82.0)$ & 1.00 & 1.00 & $239(78.4)$ & 1.00 & 1.00 \\
\hline
\end{tabular}


Table 4 Odds Ratios predicting IPVAW among ever married/cohabited women aged 15-49 by selected socio-demographic variables in East Wollega Zone, Western Ethiopia, January to April, 2011 (Continued)

\begin{tabular}{|c|c|c|c|c|c|c|}
\hline Poor & $239(74.7)$ & 0.65 (0.44 to 0.96$)$ & $0.64(0.43 \text { to } 0.96)^{*}$ & $228(71.3)$ & $0.68(0.48 \text { to } 0.99)^{*}$ & 0.70 (0.48 to 1.02$)$ \\
\hline Medium & $241(75.8)$ & 0.69 (0.47 to 1.02$)$ & 0.71 (0.47 to 1.07 ) & $228(71.7)$ & 0.70 (0.49 to 1.01$)$ & $0.76(0.52$ to 1.11$)$ \\
\hline Richer & $197(73.2)$ & $\begin{array}{l}0.60 \text { (0.40 to } 0.90) \\
*\end{array}$ & $0.61(0.40 \text { to } 0.94)^{*}$ & $186(69.1)$ & 0.62 (0.43 to 0.90$)^{*}$ & 0.65 (0.44 to 0.97 ) \\
\hline Richest & $251(76.5)$ & $0.72(0.49$ to 1.06$)$ & $0.66(0.44 \text { to } 0.99)^{*}$ & $236(72.0)$ & 0.71 (0.49 to 1.02 ) & 0.69 (0.47 to.02) \\
\hline
\end{tabular}

Adjusted for all variables in the model

COR - Crude odds Ratio, AOR - Adjusted Odds Ratio, Cl: confidence interval.* P- Value $<0.05$,** P- Value $<0.001$, $\uparrow$ - Professional, semi skilled, soldiers, police

Note: - variables not entered in the model because they were not found significant in bivariate analysis 
Table 5 Odds Ratios predicting IPVAW among ever married/cohabited women aged 15-49 by selected cultural and behavioral variables in East Wollega Zone, Western Ethiopia, and January to April, 2011

\begin{tabular}{|c|c|c|c|c|c|c|}
\hline \multirow[t]{2}{*}{ Variables } & \multicolumn{3}{|c|}{ Lifetime IPVAW } & \multicolumn{3}{|c|}{ Current (past 12 months) IPVAW } \\
\hline & No $(\%)$ & COR $(95 \% \mathrm{Cl})$ & AOR $(95 \% \mathrm{Cl})$ & No $(\%)$ & COR $(95 \% \mathrm{Cl})$ & AOR $(95 \% \mathrm{Cl})$ \\
\hline \multicolumn{7}{|c|}{ Initiation of marriage or choose $(n=1540)$} \\
\hline Both & $1026(75.5)$ & 1.00 & 1.00 & $972(71.6)$ & 1.00 & 1.00 \\
\hline Family and others & $88(78.6)$ & $1.19(0.74$ to 1.90$)$ & $1.11(0.56$ to 2.19$)$ & $82(73.2)$ & $1.08(0.70$ to 1.67$)$ & 0.87 (0.46 to 1.66$)$ \\
\hline Abduction & $63(91.3)$ & $3.40(1.50 \text { to } 7.93)^{*}$ & $3.71(1.01 \text { to } 13.63)^{*}$ & $61(88.4)$ & $3.02(1.43 \text { to } 6.37)^{*}$ & $3.02(0.93$ to 9.76$)$ \\
\hline \multicolumn{7}{|l|}{ Marriage ceremony } \\
\hline No & $379(82.1)$ & 1.00 & 1.00 & $353(71.8) 764(70.2)$ & 1.00 & 1.00 \\
\hline Yes & $800(74.2)$ & $0.63(0.48 \text { to } 0.83)^{*}$ & 0.81 (0.83 to 1.85$)$ & & $0.66(0.51 \text { to } 0.86)^{*}$ & 0.99 (0.61 to 1.61$)$ \\
\hline \multicolumn{7}{|l|}{ Dowry/bride Price } \\
\hline No & $233(82.6)$ & 1.00 & 1.00 & $218(77.3)$ & 1.00 & 1.00 \\
\hline Yes & $942(75.0)$ & $0.63(0.45 \text { to } 0.88)^{*}$ & 0.80 (0.77 to 2.00$)$ & $896(71.5)$ & $0.74(0.54 \text { to } 0.99)^{*}$ & $0.96(0.55$ to 1.68$)$ \\
\hline \multicolumn{7}{|l|}{ Current partners } \\
\hline Monogamous & $1012(74.9)$ & 1.00 & 1.00 & $960(71.1) 154(82.8$ & 1.00 & 1.00 \\
\hline Polygamous & $163(87.6)$ & $2.37(1.51 \text { to } 3.74)^{* *}$ & $3.79(1.64 \text { to } 8.73)^{*}$ & & $1.96(1.32 \text { to } 2.92)^{*}$ & $2.51(1.26 \text { to } 4.97)^{* *}$ \\
\hline \multicolumn{7}{|c|}{ Extra marital affairs of husband } \\
\hline No & $884(73.1)$ & 1.00 & 1.00 & $837(89.2)$ & 1.00 & 1.00 \\
\hline Yes & $133(89.3)$ & $3.06(2.03 \text { to } 4.62)^{* *}$ & $1.34(0.71$ to 2.52$)$ & $222(85.1)$ & $2.53(1.76 \text { to } 3.63)^{* *}$ & $1.28(0.72$ to 2.29$)$ \\
\hline \multicolumn{7}{|c|}{ Respondent drink alcohol } \\
\hline Never & $530(77.8)$ & 1.00 & 1.00 & $485(71.2)$ & 1.00 & 1.00 \\
\hline Light (occasional) & $392(70.6)$ & $0.68(0.53 \text { to } 0.88)^{*}$ & $0.59(0.41 \text { to } 0.84)^{*}$ & $380(68.6)$ & 0.88 (0.69 to 1.13$)$ & $0.82(0.54$ to 1.25$)$ \\
\hline Heavy & $256(84.2)$ & $1.52(1.06 \text { to } 2.17)^{*}$ & $1.07(0.68$ to 1.67$)$ & $251(82.6)$ & $1.91(1.36 \text { to } 2.69)^{*}$ & 1.51 (0.87 to 2.60$)$ \\
\hline \multicolumn{7}{|c|}{ Partner's drink alcohol $(n=1512)$} \\
\hline Never & $392(73.7)$ & 1.00 & 1.00 & $361(67.9)$ & 1.00 & 1.00 \\
\hline Light (occasional) & $341(69.2)$ & $0.80(0.61$ to 1.05$)$ & $0.86(0.56$ to 1.32$)$ & $329(66.7)$ & $0.95(0.73$ to 1.23$)$ & $0.92(0.60$ to 1.41$)$ \\
\hline Heavy & $424(78.1)$ & $2.40(1.73 \text { to } 3.34)^{* *}$ & $1.98(1.21 \text { to } 3.22)^{*}$ & $408(83.8)$ & $2.47(1.81-3.31)^{*}$ & $1.88(1.17 \text { to } 3.01)^{*}$ \\
\hline \multicolumn{7}{|c|}{ Fighting habit of partner } \\
\hline No & $714(70.3) 412(91.5)$ & 1.00 & 1.00 & $689(65.4)$ & 1.00 & 1.00 \\
\hline Yes & & $4.57(3.20 \text { to } 6.53)^{* *}$ & $3.96(2.52 \text { to } 6.20)^{* *}$ & $403(89.8)$ & $4.64(3.34-6.46)^{*}$ & $4.17(2.65 \text { to } 6.55)^{* *}$ \\
\hline \multicolumn{7}{|l|}{ Age at first marriage } \\
\hline 10-14 years & $23(63.9)$ & 1.00 & 1.00 & $21(58.3)$ & 1.00 & 1.00 \\
\hline $15-19$ years & $738(75.9)$ & 1.78 (0.89 to 3.58$)$ & $1.80(0.78$ to 4.15$)$ & $707(72.7)$ & 1.91 (0.97 to 3.75$)$ & 3.41 (1.31 to 8.89$)^{*}$ \\
\hline 20-24 years & $359(79.4)$ & $2.18(1.07 \text { to } 4.47)^{*}$ & 1.96 (0.83 to 4.62$)$ & $334(73.9)$ & $2.02(1.01 \text { to } 4.05)^{*}$ & $2.93(1.10 \text { to } 7.78)^{*}$ \\
\hline$\geq 25$ years & 47 (79.3) & 2.17 (0.85 to 5.50$)$ & 2.63 (0.87 to 7.99$)$ & $44(75.9)$ & $2.25(0.92$ to 5.49$)$ & $4.26(1.27 \text { to } 14.2)^{*}$ \\
\hline \multicolumn{7}{|l|}{ First sexual intercourse } \\
\hline Wanted & $817(73.9)$ & 1.00 & 1.00 & $773(69.9)$ & 1.00 & 1.00 \\
\hline Coercedt & $359(83.3)$ & $1.76(1.32 \text { to } 2.35)^{* *}$ & $1.19(0.77$ to 1.86$)$ & $342(79.4)$ & $1.66(1.27 \text { to } 2.16)^{* *}$ & $1.27(0.84$ to 1.93$)$ \\
\hline
\end{tabular}


Table 5 Odds Ratios predicting IPVAW among ever married/cohabited women aged 15-49 by selected cultural and behavioral variables in East Wollega Zone, Western Ethiopia, and January to April, 2011 (Continued)

\begin{tabular}{|c|c|c|c|c|c|c|}
\hline \multicolumn{7}{|c|}{ Witnessed family violence } \\
\hline No & $325(68.7)$ & 1.00 & 1.00 & $302(63.8)$ & 1.00 & 1.00 \\
\hline Yes & $764(81.4)$ & $2.00(1.54 \text { to } 2.56)^{* *}$ & $1.65(1.14 \text { to } 2.38)^{*}$ & $731(77.8)$ & $1.99(1.56 \text { to } 2.54)^{* *}$ & $1.66(1.17 \text { to } 2.37)^{*}$ \\
\hline \multicolumn{7}{|c|}{ Women heard/seen violence as child } \\
\hline No & $290(69.0)$ & 1.00 & 1.00 & $268(63.8)$ & 1.00 & 1.00 \\
\hline Yes & $824(81.0)$ & $1.91(1.48 \text { to } 2.48)^{* *}$ & 1.49 (1.01 to 2.19$)$ & $788(77.5)$ & $1.95(1.52 \text { to } 2.50)^{* *}$ & 1.35 (0.98 to 1.86$)$ \\
\hline \multicolumn{7}{|c|}{ History of violence of mother-in-law } \\
\hline No & $446(73.1)$ & 1.00 & 1.00 & $415(68.0)$ & 1.00 & 1.00 \\
\hline Yes & $415(81.5)$ & 1.62 (1.22 to 2.16$)^{*}$ & 1.05 (0.60 to 1.68$)$ & $398(78.2)$ & $1.69(1.29 \text { to } 2.21)^{* *}$ & 1.04 (0.66 to 1.63$)$ \\
\hline
\end{tabular}

Adjusted for all variables in the model

COR- crude odds ratio, AOR- adjusted odds ratio, Cl-confidence interval. ${ }^{*}$ P- Value $<0.05,{ }^{* *}$ P- Value $<0.001,{ }^{\dagger}$ Coerced-transactional, forced, deception

Note: - variables not entered in the model because they were not found significant in bivariate analysis 
$71 \%$ and $54 \%$ of ever married/cohabited women experienced lifetime and current IPVAW. The study also showed that $49 \%$ and $29 \%$ of women had the experience of lifetime and past 12 months physical violence, respectively. In the same study, the corresponding figure for sexual violence was $59 \%$ and $44 \%$ [17]. These variations are likely due to the inclusion of psychological violence for measuring IPVAW into the present study. Cultural differences may also explain the discrepancy [22]. The prevalence of IPVAW in this study is also higher compared to the findings of Deribew from Agaro, Ethiopia used similar method reported the prevalence of IPVAW of $51.8 \%$ with $32 \%, 33 \%$, and $46 \%$ for lifetime physical, sexual and psychological violence, respectively [18].

The high prevalence figures found for past-year and lifetime exposure for the three forms of violence indicate the fact that women's opportunities to end violence are few due to perpetration of violence being considered as normal male behavior. In other words, the subordinate role of women in the society and family allows violence to continue and keeps the divorce rates low especially among the low and middle income groups [36]. Moreover, the high prevalence in the present study might be due to the fact that women were interviewed by female data collectors who were known and familiar with the people in the community. This creates an opportunity for disclosure of violence by the women.

Another feature which was investigated in this study is the abundance of forced sexual acts in intimate relationships. It basically accounts for $58.7 \%$ during women's lifetime and $51.0 \%$ in the past 12 months which is far greater than $46 \%$ and $33 \%$ during lifetime and past 12 months in the study of Butajira, Ethiopia [17]. This showed a lot of non-consensual sex is happening in consensual marriage/cohabitation. On the other hand, the 2005 amended Criminal Code of Ethiopia [37] doesn't recognize forced sexual acts in marital relationship as crime. Accordingly it ignores the act of compelling a woman to submit to sexual intercourse within wedlock.

Despite various efforts which have been made by different governmental and non-governmental organizations to achieve MDG 3, much smaller variations were observed across the current, previous and lifetime experiences of IPVAW. However, much decline in the current practice has been expected.

The overlap of physical and psychological violence is the most commonly occurring form than the other two joint occurrences. This is consistent with studies from Nicaragua and South Africa [33,38] which is best explained as physical violence is often accompanied by psychological attacks, threatening and controlling behaviors [39]. Moreover, WHO multi-country study on VAW states that the most acts of physical violence reflect a pattern of abuse rather than an isolated incident [13]. Additionally, the present study shows the most severe violence seemed to be associated with greater overlapping of the different forms of psychological, physical and sexual violence that accounted for $56.9 \%$ of the total violence. This constitutes extremely serious situations and is much higher than $42 \%$ reported overlaps of physical and sexual violence in study from Butajira, Ethiopia [17].

There is no substantial overlap between psychological and sexual violence for women experienced any lifetime IPVAW. Again, of all abused women, 2.8\% reported the experience of isolated sexual violence in their lifetime. This suggests that forced sexual acts alone by an intimate partner were not as prevalent in this population compared with isolated sexual violence by an intimate partner reported for other developing countries of WHO multi-county study on VAW that showed $31 \%$ in Butajira and 33\% in Bangladesh [13]. The possible explanation is that women are less inclined to disclose sexual violence because it is shameful and very sensitive topic to be more pronounced in poor socio-economic country including Ethiopia.

Rural residents were less likely to report both lifetime and current experiences of IPVAW than urban residents. This is consistent with study from Philippines found a lower frequency of intimate partner violence among rural women [40]. This possibly indicated how women cope-up with urban life and what factors in the process of urbanization could be modified to decrease stress induced violence between women and men at intimate relationships. However, the finding of the current study is not consistent with the conclusion of WHO multi-country study and others that indicated rural localities presented higher rates than urban localities $[13,41]$. This might explain as gender relations in urban regions are more distant from traditional patterns and greater presence of women's movements and support services [42]. Similarly, rural communities are usually more conservative and the bedrock of the sociocultural values of traditional societies that may promote the norms and tolerance of IPVAW. This is also true in the study area.

Older age of the respondents was significantly associated with increased risk of lifetime IPVAW corroborating other study [43]. This is possibly explained that the experiences of IPVAW are persistent from time to time in which the women report their cumulative experiences in lifetime. However, this is not consistent with Fernandez idea who described as the age of woman increases she often grows in social status as she becomes not only a wife, but also a mother and a socially influential member of her community. Thus, older women are less likely to report current experience of IPVAW than younger women [44]. 
The level of education for women and men were identified as statistically significant factor of IPVAW, which is consistent with studies elsewhere $[13,42,45,46]$. This is justified as educated women have greater range of choices in partners and able to negotiate greater autonomy and control of resources within the family. This in turn helps change norms and improves socio-economic conditions that capacitate them to protect themselves from IPVAW [42].

Compared to women who had no job, female headed respondents engaged into agricultural occupation and other activities appear to experience significantly lower levels of IPVAW. This could be explained that women are autonomous and empowered when they lead their livelihood while they are the head of the household. Indeed, this is not always true in Ethiopian context for which most of the households are headed by men.

This study also shows the increasing of the household socio economic status from poorest to richest is significantly associated with decreased risk of lifetime and current experiences of IPVAW while controlled for other variables. This association goes with Jewkes's explanation that poverty and associated stress are key contributors to intimate partner violence [42]. Here, poor socioeconomic conditions contribute to violence in the family [47-49]. Although violence occurs in all socioeconomic groups, it is more frequent and severe in lower groups across such diverse settings of developed and developing nations [30,42].

Marriage by abduction increases the likelihood of experiencing lifetime IPVAW. This is so because abduction by itself is physically, psychologically, and sexually forcing a woman to have sexual intercourse often followed by marriage or cohabitation. This clearly indicates that male behaviors commonly associated with 'traditional' masculinity, which is strongly associated with IPVAW [50].

With this regard, for women who married/cohabited to polygamous husbands/partners, there is about four and two fold risks of experiencing lifetime and current IPVAW, respectively. This is consistent with the study findings from China and Uganda [51,52]. This could explain how IPVAW put women's reproductive health at risk. Hence, it was described for having multiple sexual partner could put women at increased risk for sexually transmitted infections together with violence contributes to psychological burden, low self esteem, feelings of embarrassment and humiliation [53].

On the other hand, husbands'/partners' extra marital affairs were more strongly associated with both lifetime and current experiences of IPVAW at bivariate level. Again, the associations of frequent use of alcohol by husbands/partners and increased risk of perpetrating their wives/partners is consistent with other studies elsewhere [47,54-56]. This could be attributed for heavy consumption of alcohol is thought to reduce inhibitions, cloud judgment, and impair ability to interpret social cues [57].

Moreover, male or female witnessing inter-parental violence during their childhood increases the risk of his/ her later experience of IPVAW coincides with earlier findings from Ethiopia and other countries $[17,49,55,58,59]$. It has been suggested that witnessing inter-parental violence could lead to a normative understanding of violence and regarded as a fitting means of conflict resolution [42]. With this view, violence was confirmed as a learnt behavior that passes from generation to generation [60].

Similarly, men who witness parental violence are more likely to have attitudes that condone a husband's right to control his wife and to be violent to her [61]. This is to explain why a similar belief in male control of the family and the use of violence to achieve it exist in the world. It also explains why there are certain scenarios where intimate partner violence against women is seen as being justifiable by some men [62]. On the other hand, women who witness violence against their mothers (as children) are more likely to tolerate violence by their partners and respond in a passive manner. It is possible, therefore, that in the future these silent observers themselves will be victims or perpetrators of abuse and play a role in propagating IPVAW.

As to the limitation of this study, the cross-sectional nature could cause difficulty of determining the direction of the association between study variables. The associations could only be discussed in terms of plausibility. A further limitation is that the research team interviewed only women as proxy respondents for their husbands/partners, and hence relies on women's reports only. This can be biased when it comes to reporting on husbands'/partners' characteristic and the childhood experiences. However, the proxy respondents have been shown to produce reliable estimates in other contexts especially in asking husbands'/partners' behavior including frequency of alcoholic drinking [63]. Also, some husbands/partners might be conservative for telling their own childhood and current history to their partners.

As to the strengths of this study, it has got community-based nature and the respondents have been selected by random sampling technique with relatively large sample size. Again, the team already adopted standard and validated instrument of WHO multi-country study on VAW including special training of interviewers designed to maximize disclosure of violence across different social and cultural groups [64]. In addition, the team used interviewers and supervisors who have past experiences of data collection from their respective 
community. Because of all these measures, it was found an extremely high response and prevalence rate of the study.

To the best of the investigators' knowledge, this is the first to document and identify the patterns of IPVAW over the current, previous and lifetime experiences in Ethiopia. The information on pattern and severity of abuse might warrant the concerned body to guide the development of screening, treatment, and intervention programs for abused women and their perpetrators.

\section{Conclusions}

Intimate partner violence against women is widely observed in the study area. Compared to similar studies the finding is among the highest. The study noted that more than three in four women were experienced at least one incident of IPVAW in their lifetime. Moreover, the patterns of IPVAW are similar across the time periods.

The joint occurrence of physical and psychological violence is the most commonly reported features of IPVAW. Moreover, overlapping of psychological, physical, and sexual violence accounted $56.9 \%$ of cases that indicate an extremely serious situation. Alarmingly, more than three quarter of women who experienced any physical violence had severe acts that could threaten them in their lifetime.

Area of residence, literacy status, socio-economic status, occupation, age of the respondents, and other cultural and behavioral factors were negatively or positively associated with IPVAW in the study area.

There is a need for protective efforts to break the norms that sustain women vulnerability in the society. Beside, the promotion of higher education and socioeconomic development becomes vital. Additionally, education should target to shape children during their early age. This needs an urgent attention at all levels of societal organization including policymakers, stakeholders, professionals and other concerned body. Still interventions targeting behavioral and social factors promoting IPVAW should be instituted through the involvement of different stakeholders using a multi-sectoral approach and information dissemination tools. Moreover, extensive and longitudinal research is needed to validate the current findings.

\footnotetext{
Acknowledgements

We are very much grateful to Addis Ababa University and Bill and Melinda Gates Institute, John Hopkins University for funding the study. Our thanks also go to the study participants for their willingness to participate in the research.
}

\section{Author details}

'Departments of Reproductive Health, Population and Nutrition, School of Public Health, Addis Ababa University, P.O. Box 9086 Addis Ababa, Ethiopia.
${ }^{2}$ Departments of Epidemiology and Biostatistics, School of Public Health, Addis Ababa University, Addis Ababa, Ethiopia.

\section{Authors' contributions}

All three authors were responsible for the design and conduct of the study. The statistical analysis, the interpretation of findings and drafting of the manuscript were done by the three authors. The authors read and approved the final content of the manuscript.

\section{Competing interests}

The authors declare that they have no competing interests.

Received: 17 August 2011 Accepted: 9 December 2011

Published: 9 December 2011

\section{References}

1. UN General Assembly: Declaration on the Elimination of Violence against Women Resolution A/RES/48/104; 1994 [http://www.un.org/documents/ga/ res/48/a48r104.htm].

2. Ellsberg M, Heise L: Researching Violence against Women: A Practical Guide for Researchers and Activists Washington DC, United States: World Health Organization; PATH; 2005 [http://www.PATH.org/files/GBV_rvaw_complete. pdf].

3. Krug E, Dahlberg L, Mercy J, Zwi A, Lozano R: World Report on Violence and Health Geneva; 2002 [http://www.who.int/violence_injury_prevention/ violence/world_report/en/full_en.pdf].

4. Watt C, Catty Z: Violence against women: global scope and magnitude. Lancet 2002, 359:1232-1237[http://www.hawaii.edu/hivandaids/Violence\% 20Against\%20Women\%20\%20\%20\%20Global\%20Scope\%20and\% 20Magnitude.pdf].

5. Heyse L, Ellsberg M, Gottemoeller M: Ending Violence against Women Baltimore: John's Hopkins University School of Public Health; Population Information Program; 1999, Report No.: Series L, No. 11. http://info.k4health. org/pr/l11/violence.pdf.

6. Heise L: Violence against women: the hidden health burden. World Health Stat Q 1993, 46(1):78-84[http://www.uneca.org/adfvi/documents/ UNFPA-RH-effects-of-GBV.pdf].

7. Krug E, Dahlberg L, Mercy J, Zwi A, Lozano R: The world reports on violence and health. Lancet 2002, 360(9339):1083-1088[http://www.ncbi. nlm.nih.gov/pubmed/12384003].

8. Isabel R, Juncal P, Maria R: Physical health consequences of intimate partner violence in Spanish women. Eur J Public Health 2007, 17(5):437-443[http://eurpub.oxfordjournals.org/content/17/5/437.full.pdf +html].

9. WHO: Violence against women. World Health Organization Fact sheet 2000 [http://www.int/inf-fs/en/fact.239.html].

10. David R, Michel G: The burden of diseases among the global poor. World Bank: 1993 [http://siteresources.worldbank.org/INTPAH/Resources/ Publications/Seminars/burden.pdf].

11. Campbell J: Health consequences of intimate partner violence. Lancet 2002, 359(9314):1331-1336[http://www.nnvawi.org/pdfs/alo/Campbell_1. pdf].

12. Campbell J, Abrahams N, Martin L: Perpetration of violence against intimate partners: health care implications from global data. CMAJ 2008, 179(6):511-512[http://www.ncbi.nlm.nih.gov/pmc/articles/PMC2527385/pdf/ 20080909s00006p511.pdf].

13. Garcia M, Jansen H, Ellsberg M, Watts C: WHO Multi-Country Study on Women's Health and Domestic Violence against Women: Initial Results on Prevalence, Health Outcomes and Women's Response Geneva: World Health Organization; 2005 [http://www.onlinewomeninpolitics.org/ sourcebook_files/Resources.2/Tools-\%20Multi-country\%20Study\%20on\% 20Women's\%20Health\%20and\%20Domestic\%20Violence\%20against\% 20Women.pdf].

14. Garcia $M$, Jansen $H$, Ellsberg $M$, Heise $L$, Watts $C$ : Prevalence of intimate partner violence: findings from the WHO multi country study on women's health and domestic violence. Lancet 2006, 368:1260-1269 [http://www.who.int/gender/violence/who_multicountry_study/ media_corner/Prevalence_intimatepartner_WHOStudy.pdf].

15. Heise L: Violence against women: an integrated, ecological framework. Violence against Women 1998, 4:262-290[http://vaw.sagepub.com/content/4/ 3/262.short] 
16. A National Report on Progress made in the Implementation of the Beijing Platform for Action Beijing + 10) Ethiopia, Prime Minister Office/ Women's Affairs Sub Sector. 2004 [http://www.un.org/womenwatch/daw/ Review/responses/ETHIOPIA-English.pdf].

17. Gossaye Y, Deyessa N, Berhane Y, Ellsberg M, Emmelin M, Ashenafi M, Alem A, Negash A, Kebede D, Kullgren G, Ulf H: Butajira rural health program: womens life events study in rural Ethiopia. Ethiop J Health Dev 2003, 17(Suppl 2):1-51[http://www.un.org/womenwatch/daw/Review/ responses/ETHIOPIA-English.pdf].

18. Deribew A: Magnitude and risk factors of intimate partner violence against women in Agaro town, South West Ethiopia. Ethiopia J Health Sci 2007, 17(2):1-13[http://docs.google.com/viewer].

19. Dibaba Y: Prevalence and correlates of intimate partner physical violence against women in Kofale District, Ethiopia. Trop Doct 2008, 38(1):52-54 [http://www.ncbi.nlm.nih.gov/pubmed/18302872].

20. Berhane Y: Ending Domestic violence against women in Ethiopia. Ethiopia J Health Dev 2004, 18(3):131-132[http://ejhd.uib.no/ejhdv18-no3/ 131.EDITORIAL.pdf].

21. Central Statistical Agency [Ethiopia] and ORC Macro: Ethiopia Demographic and Health Survey: 2005. Addis Ababa, Ethiopia and Calverton, Maryland, USA: Central Statistical Agency and ORC Macro 2006 [http://www. measuredhs.com/pubs/pub_details.cfm?id=596].

22. CSA: Statistical Abstract of Federal Democratic Republic of Ethiopia. CSA Addis Ababa, Ethiopia; 2010.

23. BSS: HIV/AIDS prevention and control office (HAPCO). Behavioural Surveillance Survey in Ethiopia 2002.

24. Binson D, Canchola JA, Catania JA: Random selection in a telephone survey: a comparison of the kish, next-birthday, and last-birthday methods. J Official Stat 2000, 16:53-59[http://www.lisproject.org/ publications/liswps/358.pdf].

25. WHO: The WHO Multi-Country Study on Women's Health and Domestic Violence: Notes on Use of the Questionnaire [http://www.who.int/.../files/ .../FinalVAWprogressreportforwebpagewithoutcover.pdf], (Version 10, 20 September 2003).

26. Straus M, Hamby S, Boney-McCoy S, Sugarman D: The revised Conflict Tactics Scales (CTS2): development and preliminary psychometric data. J Family Issues 1996, 17:283-316[http://jfi.sagepub.com/content/17/3/283. short].

27. Vyas S, Kumaranayake L: Constructing socio-economic status indices: how to use principal components analysis. Health Policy Plan 2006, 26(1):64-73 [http://www.ncbi.nlm.nih.gov/pmc/articles/PMC2740686/pdf/jhpn0026-0064. pdf].

28. Heise L, Nahid T, Kant M: Sexual Coercion and Reproductive Health: A Focus on Research New York: Population Council; 1995 [http://www.popcouncil. org/pdfs/scoer.pdf].

29. Ellsberg M, Heise L, Pena R, Agurto S, Winkvist A: Researching domestic violence against women: methodological and ethical considerations. Stud Fam Plann 2001, 32(1):1-16[http://gender.care2share.wikispaces.net/file/ view/(13)ResearchingDVMethods.pdf].

30. Vung N, Ostergren P, Krantz G: Intimate partner violence against women in rural Vietnam - different socio-demographic factors are associated with different forms of violence: need for new intervention guidelines? BMC Public Health 2008, 8:55[http://www.ncbi.nlm.nih.gov/pmc/articles/ PMC2275257/pdf/1471-2458-8-55.pdf].

31. Gil-Gonzalez G, Vives C, Ruiz M, Carrasco P, Alvarez D: Childhood experiences of violence in perpetrators as a risk factor of intimate partner violence: a systematic review. J Pub Health 2008, 30(1):14-22 [http://jpubhealth.oxfordjournals.org/content/30/1/14.full.pdf+html].

32. WHO: Putting women first: Ethical and safety recommendations for research on domestic violence against women Geneva; 2001 [http://www.who.int/ gender/violence/womenfirtseng.pdf].

33. Ellsberg M, Pen R, Herrera A, Liljestrand J, Winkvis A: Candies in hell: women's experiences of violence in Nicaragua. Soc Sci Med 2000, 51:1595-1610[http://www.caresci.gu.se/infoglueCalendar/digitalAssets/ 1760631588_BifogadFil_artiklar070228.pdf].

34. Ruiz-Perez I, Plazaola-Castano J, Vives-Cases C: Methodological issues in the study of violence against women. J Epidemiol Community Health 2007, 61(2):26-31[http://jech.bmj.com/content/61/Suppl_2/ii26.full.pdf].

35. Deyessa N, Berhane Y, Ellsberg M, Emmelin M, Kullgren G, Ulf H: Intimate partner violence and depression among women in rural Ethiopia: a cross-sectional study. Clin Pract Epidemiol in Ment Health 2009, 5:8[http:// www.cpementalhealth.com/content/5/1/8]

36. Ali T, Asad N, Mogren I, Krantz G: Intimate partner violence in urban Pakistan: prevalence, frequency, and risk factors. Int J of Women's Health 2011, 3:105-115[http://www.dovepress.com/intimate-partner-violence-inurban-pakistan-prevalence-frequency-and-r-peer-reviewed-article-IJWH]

37. The criminal code of the Federal Democratic Republic of Ethiopia, Proclamation No. 414/2004. Addis Ababa; 2005 [http://www.lo.org/dyn/ natlex/docs/ELECTRONIC/70993/75092/F1429731028/ETH70993.pdf].

38. Dunkle KL, Jewkes RK, Brown HC, Gray GE, Mclntyre JA, Harlow SD: Gender based power, relationship power and risk of HIV in women attending antenatal clinic in South Africa. Lancet 2004, 363(9419):1415-1421[http:// www.ncbi.nlm.nih.gov/pubmed/15121402].

39. Ursula L: Intimate partner violence Fact sheet. 2009 [http://www.mrc.ac.za/ crime/intimatepartner.pdf].

40. Hindin M, Adair L: Who's at risk? Factors associated with intimate partner violence in the Philippines. Soc Sci Med 2002, 55(8):1385-1399[http://www. ncbi.nlm.nih.gov/pubmed/12231016].

41. Karamagi C, Tumwine1 J, Tylleskar T, Heggenhougen K: Intimate partner violence against women in eastern Uganda: implications for HIV prevention. BMC Public Health 2006, 6:284[http://www.ncbi.nlm.nih.gov/ pmc/articles/PMC1660563/pdf/1471-2458-6-284.pdf].

42. Jewkes R: Intimate partner violence: causes and prevention. Lancet 2002, 359:1423-1429[http://www.ayamm.org/english/Violence\%20against\% 20women\%201.pdf]

43. Hedin LW, Janson PO: Domestic violence during pregnancy: the prevalence of physical injuries, substance use, abortions and miscarriages. Acta Obstet Gynecol Scand 2000, 79:625-630[http:// onlinelibrary.wiley.com/doi/10.1034/j.1600-0412.2000.079008625.x/pdf].

44. Fernandez M: Domestic violence by extended family members in India. $J$ Interpers Violence 1997, 12(3):433-455[http://aje.oxfordjournals.org/content/ 150/4/417.full.pdf].

45. Yigzaw T, Yibrie A, Kebede Y: Domestic violence around Gondar in NorherWest Ethiopia. Ethiop J Health Dev 2004, 18(3):133-139[http://www. cih.uib.no/journals/EJHD].

46. Tjaden $\mathrm{P}$, Thoennes $\mathrm{N}$ : Extent, nature and consequences of intimate partner violence: findings from the National Violence Against Women Survey Washington, DC: National Institute of Justice, Centers for Disease Control and Prevention; 2000 [http://www.ojp.usdoj.gov/nij].

47. Koenig M, Ahmed S, Hossain M, Khorshed A: Domestic violence in Rakai, Uganda: evidence from a community based survey. Bull World Health Organ 2003, 81:53-60[http://www.who.int/bulletin/Koenig0103.pdf].

48. Valladares $\mathrm{E}$, Pena $\mathrm{R}$, Persson L, Ulf H: Violence against pregnant women: prevalence and characteristics. A population based study in Nicaragua. Br J Obstet Gynaecol 2005, 112:1243-1248[http://www.ncbi.nlm.nih.gov/ pubmed/16101603].

49. Jeyaseelan L, Kumar N, Neelakantan A, Peedicayil R, Pillai N, Duvvury: Physical spousal violence against women in India: some risk factors. J Biosoc Sci 2007, 39(5):657-670[http://www.ncbi.nlm.nih.gov/pubmed/ 17349066].

50. Abramsky T, Watts CH, Garcia C, Devries K, Kiss L, Ellsberg M, Jansen HA, Heise L: What factors are associated with recent intimate partner violence? findings from the WHO multi-country study on women's health and domestic violence. BMC Public Health 2011, 11(109):1-17[http:// www.biomedcentral.com/1471-2458/11/109].

51. Xu X, Zhu H, Koenig M, Moch V, Campbell J: Prevalence of and risk factors for intimate partner violence in China. Am J Public Health 2005, 95:78-85 [http://ajph.aphapublications.org/cgi/reprint/95/1/78.pdf].

52. Kaye D, Mirembe F, Bantebya G: Risk factors, nature and severity of domestic violence among women attending antenatal clinic in Mulago hospital, Kampala, Uganda. Cent Aft J Med 2002, 48(5-6):4-68[http://www. ncbi.nlm.nih.gov/pubmed/12971161].

53. Orava T, McLeod P, Sharpe D: Perceptions of control, depressive symptomatology, and self-esteem of women in transition from abusive relationships. J Fam Violence 1996, 11:167-186[http://www.springerlink.com/ content/57n6qk754q4w2x24/].

54. Djikanovic B, Jansen $H$, Otasevic S: Factors associated with intimate partner violence against women in Serbia: a cross-sectional study. J Epidemiol Community Health 2010, 64:728-735[http://jech.bmj.com/content/ 64/8/728.full.pdf]. 
55. Kishor S, Kiersten J: Profiling Domestic Violence - A Multi-Country Study Calverton, Maryland: ORC Macro; 2004 [http://www.measuredhs.com/pubs/ pdf/OD31/OD31.pdf].

56. Kimuna SR, Djamba YK: Gender based violence: correlates of physical and sexual wife abuse in Kenya. J Fam Violence 2008, 23(5):333-342[http:// www.springerlink.com/content/41205631655v3264/].

57. Koss M, Gaines J: The prediction of sexual aggression by alcohol use, athletic participation and fraternity affiliation. J Interpers Violence 1993, 8:94-106[http://jiv.sagepub.com/content/8/1/94.abstract].

58. Andrew R, Maria M, Orlando B: The costs and impacts of gender-based violence in developing countries: Methodological considerations and new evidence. 2004 [http://siteresources.worldbank.org/INTGENDER/ Resources/costsandimpactsofgbv.pdf].

59. Koenig MA, Stephenson S, Ahmed SJ, Jejeebhoy, Campbell J: Individual and contextual determinants of domestic violence in North India. Am J Public Health 2006, 96(1):132-138[http://ajph.aphapublications.org/cgi/ reprint/96/1/132.pdf].

60. Stith SM, Rosen KH, Middleton KA, Busch AL, Lundeberg K, Carlton RP: The intergenerational transmission of spouse abuse: a meta-analysis. J Marriage and the Family 2000, 62:640-654[http://www.jstor.org/stable/ 1566786].

61. Martin SL, Moracco KE, Garro J, Tsui AO, Kupper LL, Chase JL, Campbell JC: Domestic violence across generations: findings from northern India. Int $J$ Epidemiol 2002, 31:560-572[http://ije.oxfordjournals.org/content/31/3/560.full. pdf + html].

62. Roberts A, Gilman S, Fitzmaurice G, Decker M, KC K: Witness of intimate partner violence in childhood and perpetration of intimate partner violence in adulthood. Epidemiol 2010, 21(6):809-818[http://www.ncbin.nlm. nih.gov/pubmed/20811285].

63. Graham P, Jackson R: Primary versus proxy respondents: comparability of questionnaire data on alcohol consumption. Am J Epidemiol 1993, 138:443-452[http://hinari-gw.who.int/whalecomaje.oxfordjournals.org/ whalecom0/content/138/6/443.abstract].

64. Jansen H, Watts C, Ellsberg M, Heise L, Garcia CM: Interviewer training in the WHO Multi-country study on women's health and domestic violence. Violence against Women 2004, 10:831-849[http://hinari-gw.who.int/ whalecomvaw.sagepub.com/whalecom0/content/10/7/831.full.pdf+html].

\section{Pre-publication history}

The pre-publication history for this paper can be accessed here: http://www.biomedcentral.com/1471-2458/11/913/prepub

\section{doi:10.1186/1471-2458-11-913}

Cite this article as: Abeya et al.: Intimate partner violence against women in western Ethiopia: prevalence, patterns, and associated factors. BMC Public Health 2011 11:913.

\section{Submit your next manuscript to BioMed Central and take full advantage of:}

- Convenient online submission

- Thorough peer review

- No space constraints or color figure charges

- Immediate publication on acceptance

- Inclusion in PubMed, CAS, Scopus and Google Scholar

- Research which is freely available for redistribution

Submit your manuscript at www.biomedcentral.com/submit
Ciomed Central 